\title{
Majapahit Pun Runtuh Karena Ulah Para Elit Politiknya
}

\section{Baskoro Daru Tjahjono}

Keywords: east java, kingdom, politics, dynamics, trowulan, social power

\section{How to Cite:}

Tjahjono, B. D. (2004). Majapahit Pun Runtuh Karena Ulah Para Elit Politiknya. Berkala Arkeologi, 24(1), 38-46. https:// doi.org/10.30883/jba.v24i1.892

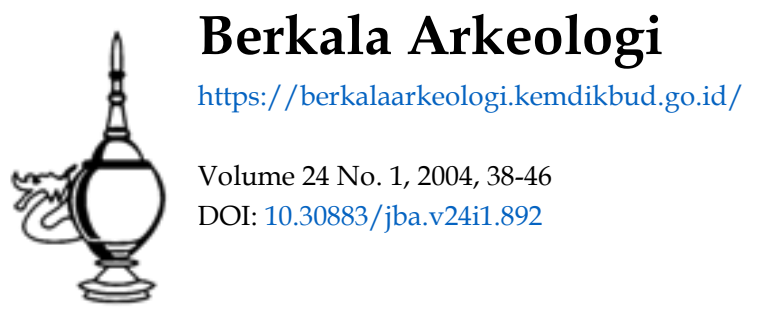

\section{c) (i) (5)}

This work is licensed under a Creative Commons Attribution-NonCommercial-ShareAlike 4.0 International License. 


\title{
MAJAPAHIT PUN RUNTUH KARENA \\ ULAH PARA ELIT POLITIKNYA
}

\author{
Baskoro Daru Tjahjono
}

$\mathbf{P}$ endahuluan

Sebuah negara akan menjadi besar dan makmur jika pemimpin dan para elit politiknya kompak. Dalam arti mereka menjalankan tugas pokok dan fungsinya masing-masing secara bertanggung jawab untuk kesejahteraan rakyatnya. Jika sebaliknya maka akan terjadi benturan-benturan kepentingan, yang pada akhirnya akan merugikan rakyat. Akibat yang lebih parah adalah akan menghancurkan kehidupan berbangsa dan bernegara. Siapakah para elit politik itu?

Dalam tulisan ini para elit politik yang dimaksud adalah para petinggi atau para pejabat di lingkungan kerajaan Majapahit. Raja adalah penguasa tertinggi di kerajaan Majapahit, tetapi dalam menjalankan roda pemerintahan sehari-hari ia tidaklah sendirian. Raja dibantu oleh perangkat pemerintahan seperti patih (mahapatih), mahamantri katrini, dharma dhyaksa, dan pejabat-pejabat lain yang termasuk dalam pejabat istana maupun pejabat-pejabat daerah.

Patih (mahapatih) merupakan jabatan pusat di ibukota, yang memegang pengawasan atas pejabat-pejabat militer dan pemerintahan sipil. Rakryan Mahamantri Katrini terdiri dari tiga orang, yaitu: Rakryan Mahamantri i Hino, Rakryan Mahamantri I Halu, dan Rakryan Mahamantri I Sirikan. Para pejabat ini mempunyai kedudukan penting sesudah raja dan mereka itulah yang mendapatkan perintah secara langsung dari raja. Tetapi mereka bukanlah para pelaksana perintah raja, karena perintah itu diturunkan kepada para pejabat di bawahnya. Dharma dhyaksa menjalankan fungsi yurisdiksi agama yang meliputi agama Siwa (dharma dhyaksa ring kasaiwan) dan agama Buddha (dharma dhyaksa ring kaboddhan). Jabatan-jabatan lain yang termasuk pejabat istana adalah tumenggung (panglima), demung (pengatur rumah tangga istana), kanuruhan (penghubung keluar istana), rangga (pembantu panglima), dan juru pengalasan (komandan pengawal istana). Sedangkan para pejabat daerah (adhipati) adalah wakil tertinggi kekuasaan raja di daerah. Sebagai pembesar daerah para adhipati itu menjadikan diri mereka sebagai sekelompok orang terkemuka karena statusnya, dan seringkali dapat mendesak penguasa-penguasa dan pejabat-pejabat istana tertinggi (Kartodirdjo, 1993: 36-37).

Para pejabat tinggi itulah yang merupakan elit politik kerajaan Majapahit, karena mereka ikut menjalankan kekuasaan tertinggi raja. Namun rajalah yang memerintah pelaksanaan kekuasaan tertinggi dan berbagai-bagai lambang yang bersifat magis dan mistis, yang mewujudkan kualitas perlengkapan-perlengkapan kekuasaan itu. Raja 
memegang pengawasan tertinggi atas kekuatan militer dan administrasi (Kartodirdjo, 1993: 37). Para elit politik itu sebagian juga mempunyai atau berkuasa atas para prajurit lebih-lebih para penguasa daerah. Oleh karena itu, seringkali terjadi pemberontakan-pemberontakan oleh para elit politik jika mereka tidak puas atas kepemimpinan raja atau jika mereka ingin melepaskan diri dari kekuasaan raja. Majapahit pun tak lepas dari konflik-konflik akibat ulah para elit politiknya. Sejak awal berdirinya hingga keruntuhannya negara itu mengalami pasang surut. Ada kalanya mengalami masa-masa suram akibat banyaknya pemberontakan, ada kalanya mengalami masa gemilang dan mencapai jaman keemasan. Kemudian surut kembali sebagai anti klimaks hingga keruntuhannya.

Sirna Ilang Kertaning Bhumi yang berarti tahun 1400 Ç (1478 M) pernah diyakini sebagai tahun berakhirnya kerajaan Majapahit. Namun Hasan Jafar -- dalam bukunya "Girindrawarddhana Beberapa Masalah Majapahit Akhir" -- mengatakan bahwa pada tahun itu Majapahit masih berdiri, candra sengkala itu hanya menggambarkan suatu peristiwa perebutan kekuasaan atas tahta kerajaan Majapahit dari tangan Bhre Kertabhumi oleh Girindrawarddhana Dyah Ranawijaya (Djafar, 1978: 107-108).

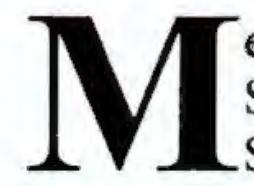

\section{embangun Majapahit}

Semua orang tahu Majapahit adalah sebuah kerajaan besar setelah Sriwijaya. Bahkan luas wilayahnya telah melebihi luas wilayah kekuasaan kerajaan Sriwijaya yang merupakan kerajaan maritim pertama di Nusantara. Majapahit adalah kerajaan agraris sekaligus maritim. Tetapi untuk mencapai kebesaran itu tidaklah mudah. Kerajaan ini dibangun dari bawah dan tidak serta merta menjadi besar, di dalam perjalanan sejarahnya harus mengalami pasang-surut. Berawal dari sebuah hutan Tarik yang tak dihuni orang dibangun sebuah desa, pada akhirnya berkembang menjadi sebuah kerajaan besar yang bernama Majapahit.

Berdirinya kerajaan Majapahit tak dapat dipisahkan dari sejarah kerajaan Singasari, karena pendiri kerajaan Majapahit masih merupakan keturunan dinasti pendiri kerajaan Singasari. Jadi boleh dikatakan Majapahit merupakan kelanjutan dari kerajaan Singasari. Ketika Jayakatwang dari Kadiri menyerang Singasari dan berhasil membunuh Kertanagara raja Singasari, maka Wijaya menantunya menjadi pelarian karena dikejar-kejar musuh. Prasasti Kudadu menyebutkan bahwa Raden Wijaya beserta 12 orang prajuritnya yang masih setia sepakat mengungsi ke Madura dan berlindung kepada Arya Wiraraja. Wijaya dan para prajuritnya menuju ke Pandakan tetapi Gajah Panggon ditinggal di rumah kepala desa Pandakan karena sakit. Kemudian mereka menuju ke Datar, dan pada malam harinya naik perahu menuju ke Madura. Setibanya di Madura Raden Wijaya menghadap Arya Wiraraja (Darmosoetopo, 1993: 52). 
Atas saran Arya Wiraraja yang ahli strategi, Wijaya berhasil mengabdi kepada Jayakatwang dan diberi tanah di hutan Tarik. Dengan bantuan Wiraraja yang mengerahkan orang Madura sebagai tenaga kerja, hutan tarik itu dibangun menjadi sebuah kota. Kemudian Raden Wijaya tinggal di sana dan berkeinginan untuk menyerang Jayakatwang. Akan tetapi oleh Wiraraja disarankan untuk menangguhkan rencana tersebut sambil menunggu kedatangan tentara Tartar yang hendak menghukum Kertanagara. Ketika tentara Tartar datang, Wijaya memanfaatkan kesempatan itu untuk merebut kembali kerajaan Singasari dari tangan Jayakatwang (Darmosoetopo, 1993: 53).

Setelah berhasil mengalahkan Jayakatwang, Wijaya berbalik menyerang tentara Tartar sehingga kocar-kacir, dan yang berhasil menyelamatkan diri kembali ke negerinya. Selanjutnya hutan Tarik yang telah menjadi sebuah kota dibangun menjadi Kerajaan Majapahit. Wijaya dinobatkan menjadi raja pertama dengan nama abiseka Kertarajasa Jayawardhana. Di bawah pemerintahannya Majapahit yang merupakan kelanjutan dari Kerajaan Singasari bertumbuh menjadi besar. Raden Wijaya memerintah kerajaan Majapahit selama 16 tahun, yaitu tahun 1215-1231 C (1293-1309 M). la adalah anak Dyah Lembu Tal, cucu Mahisa Campaka (Narasinghamurti), buyut Mahisa Wongateleng, dan piut (canggah) Ken Arok dan Ken Dedes. Dengan demikian Wijaya masih keturunan Ken Arok dan Ken Dedes secara langsung. Ia juga masih keponakan Raja Kertanagara (Darmosoetopo, 1993: 52-53). Sumber prasasti (Sukamrta dan Balawi) dan Nagarakertagama menyebutkan bahwa Raden Wijaya kawin dengan 4 orang putri Kertanagara, yaitu Sri Parameswari Dyah Dewi Tribhuwaneswari, Sri Mahadewi Dyah Dewi Narendraduhita, Sri Jayendradewi Dyah Dewi Prajnaparamita, dan Sri Rajendradewi Dyah Dewi Gayatri.

Tidak lama setelah penobatan Kertarajasa menjadi raja Majapahit, kembalilah pasukan yang dahulu dikirim oleh raja Kertanagara ke Nusantara. Mereka membawa hasil yang gemilang dengan menundukkan raja-raja Nusantara. Selanjutnya para pengikut Kertarajasa yang setia dan berjasa dalam perjuangan mendirikan kerajaan Majapahit diberi kesempatan untuk menikmati hasil perjuangan mereka dan diangkat menjadi pejabat tinggi dalam pemerintahan. Wiraraja diangkat sebagai mantri mahawiradikara, Nambi diangkat menjadi rakryan mapatih, Pu Sora sebagai rakryan apatih di Daha, Wenang atau Lawe diangkat menjadi amancanagara di Tuban dan adhipati di Datara, dan pemimpin pasukan ke Malayu dijadikan panglima perang dengan mendapat nama Kebo Anabrang (Poespowardojo, 1984: 428).

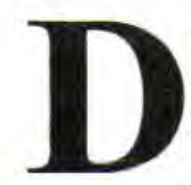

\section{uet Hayam Wuruk-Gadjahmada}

Hayam Wuruk adalah raja keempat Majapahit, yaitu setelah Kertarajasa, Jaya nagara, dan Tribhuwanattunggadewi. Hayam Wuruk dinobatkan menjadi raja Majapahit tahun $1350 \mathrm{M}$, menggantikan ibunya Tribhuwanottunggadewi. Ia bergelar 
Sri Rajasanagara dan terkenal dengan sebutan Bhra Hyang Wekas ing Sukha (Darmosoetopo, 1993: 54). Pada masa pemerintahannya yang menjabat mahapatih adalah Gajah Mada. Di bawah kepemimpinan Raja Hayam Wuruk dan Mahapatih Gadjahmada, Majapahit mencapai puncak kejayaannya dan berhasil mempersatukan Nusantara di bawah panji-panji Majapahit.

Dengan kekuatan angkatan bersenjatanya berbagai negeri di seantero Nusantara berhasil ditaklukkan. Keberhasilan mempersatukan Nusantara ini tidak lepas dari kebesaran dan keberanian Gadjahmada dalam menjalankan gagasan politik nusantaranya yang telah dicetuskan melalui sumpah palapa di hadapan raja Tribhuwanottunggadewi dan para pembesar kerajaan Majapahit. Selain itu juga ditunjang oleh duet kepemimpinan Hayam Wuruk dan Gadjahmada yang sangat solid. Tetapi ketika kedua pemimpin ini tak sepaham lagi maka perpecahan negeri pun tak terelakkan.

Hayam Wuruk adalah raja yang sangat berwibawa, sedangkan Gadjahmada adalah mahapatih yang ahli strategi. Di tangan Gadjahmada musuh yang sangat beratpun berhasil ditaklukkannya. Daerah-daerah yang berhasil ditaklukkan dan dipersatukan di bawah panji-panji Majapahit meliputi hampir seluas wilayah Indonesia sekarang, dari Sumatra di bagian barat sampai Maluku dan Irian di bagian timur, bahkan sampai ke beberapa negara tetangga di wilayah Asia Tenggara (Poespowardojo, 1984: 436). Selain berhasil mempersatukan wilayah Nusantara Hayam Wuruk juga berhasil meningkatkan kemakmuran rakyatnya melalui berbagai kegiatan di bidang perekonomian. Hasil pemungutan pajak dan persembahan upeti dimanfaatkan untuk menyejahterakan seluruh kerajaan di berbagai bidang. Berita ini diketahui dari Nagarakertagama maupun prasasti-prasasti yang berasal dari masa pemerintahannya. Raja memerintahkan mendirikan bendungan-bendungan dan saluran-saluran pengairan, serta pembukaan tanah-tanah baru untuk pertanian. Tempat-tempat penyeberangan didirikan di sungai-sungai besar untuk memudahkan lalu-lintas antar daerah. Selain memperhatikan kemakmuran rakyatnya raja Hayam Wuruk juga sangat memperhatikan keadaan daerah-daerah kerajaan. Ia bersama para pembesar kerajaan sering melakukan perjalanan kenegaraan meninjau daerah-daerah di wilayah Majapahit. Perjalanan raja Hayam Wuruk ke berbagai daerah itu tercatat dalam Nagarakertagama, antara lain perjalanan ke Pajang tahun $1351 \mathrm{M}$, ke Lasem tahun $1354 \mathrm{M}$, ke daerah pantai selatan (Lodaya) tahun $1357 \mathrm{M}$. Selanjutnya perjalanan ke daerah Lumajang tahun 1359 M, ke daerah Tirib dan Sempur tahun $1360 \mathrm{M}$, ke daerah Balitar tahun 1361, dan tahun 1363 raja Hayam Wuruk mengunjungi Simping dan meresmikan sebuah candi yang baru selesai dipindahkan (Poespowardojo, 1984: 437-438).

Akan tetapi awal malapetaka itu terjadi, ketika Majapahit hendak menaklukkan negeri Pasundan, negeri yang pantang menyerah. Maka segala daya dikerahkan oleh 
Gadjahmada untuk dapat menaklukkan negeri itu. Betapa malunya jika ia tak berhasil menaklukkan negeri Pasundan sebab ia telah bersumpah untuk mempersatukan seluruh Nusantara di bawah panji-panji Majapahit. Negeri-negeri yang jauh telah berhasil ditaklukkannya kenapa negeri yang tidak terlalu jauh ini belum tunduk kepada Majapahit.

Untuk dapat menaklukkan negeri Pasundan itu maka disusunlah strategi yang sangat jitu tetapi sangat besar resikonya, baik bagi dirinya sebagai mahapatih, bagi negara dan rakyatnya, maupun bagi rajanya sendiri. Namun untuk dapat memenuhi ambisi politiknya tersebut apapun resikonya akan ditempuh.

Sang Gadjahmada pun menyusun rencana yang sangat strategis. Ketika raja Hayam Wuruk hendak mempersunting putri Sunda -- Dyah Pitaloka - sebagai permaisurinya, Gajah Mada menghendaki agar putri itu dipersembahkan oleh raja Sunda kepada raja Majapahit sebagai tanda pengakuan tunduk. Namun para pembesar kerajaan Sunda tidak setuju dengan sikap Gajah Mada tersebut, sehingga terjadilah peperangan di Bubad yang terkenal dengan nama Pabubad. Raja Sunda beserta seluruh pengiringnya gugur dalam peperangan itu (Poespowardojo, 1984: 436).

Majapahit memang berhasil mengalahkan kerajaan Sunda, namun peristiwa itu dianggap sebagai kegagalan politik Gajah Mada. Oleh karena itu, Prapanca tidak mencatatnya dalam Nagarakertagama karena peristiwa itu tidak menunjang kebesaran Majapahit. Dengan terjadinya perang Bubad maka berakirlah karier politik Gajah Mada. Sebagai wujud pertanggungjawabannya iapun kemudian mengundurkan diri dari jabatannya (mukti palapa). Dalam Pararaton disebutkan: "samangka sira Gajahmada mukti palapa" (Poespowardojo, 1984: 437). Sepeninggal Gajah Mada kebesaran Majapahit pun berangsur-angsur mulai surut, karena tidak ada pengganti yang sepadan dengannya.

\section{$\mathbf{U}$}

\section{lah Para Elit Politik Majapahit}

Sejak awal berdirinya, Majapahit tak lepas dari ulah para elit politik yang berusaha memecah persatuan dan kesatuan kerajaan Majapahit. Hal ini disebabkan karena ketidakpuasan mereka atas kepemimpinan raja atau pun tidak puas akan kedudukan atau jabatan yang mereka terima. Ketika Raden Wijaya telah menjadi raja ia ditinggalkan beberapa teman sejawatnya pada waktu menghadapi Jayakatwang dan tentara Kubhilai Khan. Walaupun mereka telah mendapatkan kedudukan yang tinggi tetapi sebagian dari mereka tidak puas atas anugerah atau jabatan yang diberikan raja. Ranggalawe yang tidak jadi diangkat menjadi patih melawan raja sehingga terjadi peperangan yang disebut Paranggalawe pada tahun $1217 \mathrm{C}$ (1295 M). Wiraraja tidak mau bekerjasama lagi dengan Raden Wijaya karena tidak jadi mendapat anugerah seperdua dari tanah Jawa. Tiga tahun setelah Paranggalawe terjadi 
Pasora. Namun pemberontakan-pemberontakan itu dapat diatasi oleh Raden Wijaya (Darmosoetopo, 1993: 53). Terjadinya peperangan itu sebenarnya dipicu oleh munculnya seorang tokoh yang menjadi biang kerusuhan di Majapahit, yaitu Mahapati. Ia menjadi tokoh yang sering mengadu domba antara raja dengan para pejabat tinggi kerajaan. Selain Ranggalawe dan Lembu Sora sasaran lainnya adalah Nambi, karena sebenarnya ia menginginkan kedudukan sebagai patih amangkubhumi.

Raden Wijaya kemudian digantikan oleh Jayanagara. Pada masa pemerintahannya inilah banyak sekali pemberontakan-pemberontakan. Pagajahbiru terjadi pada tahun 1236 Ç (1314 M). Selanjutnya terjadi Pamadana, Pawagal, dan Palasem. Kemudian pada tahun $1238 \mathrm{Ç}(1316 \mathrm{M})$ terjadi pemberontakan yang dilakukan oleh Nambi yang disebut Panambi. Pada tahun 1240 Ç (1318 M) terjadi pemberontakan yang dilakukan oleh Semi yang disebut Pasemi. Pemberontakan paling besar dan hampir meruntuhkan kerajaan Majapahit dilakukan oleh Kuti yang disebut Pakuti (Darmosoetopo, 1993: 54). Akhirnya raja Jayanegara dibunuh oleh Tanca ketika ia diminta untuk mengobati bisul sang raja, sedangkan Tanca kemudian dibunuh oleh Gajah Mada. Menurut Pararaton raja meninggal tahun 1250 Ç $(1328 \mathrm{M})$ dan didharmakan di Kapompongan (Srenggapura), sedangkan menurut Nagarakrtagama, Jayanegara didharmakan di Silapetak dan Bubat bersifat Wisnuistis, serta di Sukalila bersifat Buddhistis (Darmosoetopo, 1993: 54).

Jayanagara digantikan oleh adik perempuannya yaitu bhre Kahuripan. Ia naik tahta bergelar Tribhuwanottunggadewi Jayawisnuwardhani. Pada masa pemerintahannya keadaan Majapahit mulai membaik. Hanya ada beberapa gangguan keamanan yaitu di Sadeng dan Keta pada tahun 1331 M, yang semuanya dapat diatasi oleh Gajah Mada. Setelah peristiwa itu Gajah Mada diangkat menjadi patih amangkubhumi menggantikan Arya Tadah. Selain itu kitab Pararaton juga menyebutkan bahwa Gajah Mada bersumpah di hadapan raja dan para pembesar Majapahit, ia tidak akan amukti palapa sebelum dapat menundukkan nusantara, yaitu Gurun, Seran, Tanjungpura, Haru, Pahang, Dompo, Bali, Sunda, Palembang, dan Tumasik (Poesponegoro, 1984: 434).

Tribhuwanottunggadewi digantikan oleh Hayam Wuruk putranya. Pada masa pemerintahannya ia didampingi oleh Gajah Mada. Pada masa pemerintahannya ini Majapahit mengalami masa keemasan. Namun sepeninggal raja Hayam Wuruk dan Patih Amangkubhumi Gajah Mada, Majapahit mengalami kesuraman dan muncul suatu masalah yaitu perebutan kekuasaan dan pertentangan keluarga mengenai hak waris atas tahta kerajaan. Sebelumnya Hayam Wuruk telah membagi kerajaan menjadi dua yaitu di sebelah barat (Majapahit) diperintah oleh Wikramawarddhana dan kerajaan di timur (daerah Balambangan) diperintah oleh Wirabhumi, anak Hayam Wuruk dari istri selir. Sedangkan Wikramawarddhana adalah keponakan dan menantu Hayam Wuruk. Dia naik tahta karena mengawini Kusumawarddhani, anak Hayam 
Wuruk dari parameswari. Dengan demikian Kusumawarddhani-lah yang sebenarnya berhak atas tahta kerajaan karena sebagai putri mahkota. Mungkin karena keadaan itulah menyebabkan ketidakpuasan salah satu pihak, sehingga pada masa pemerintahan Wikramawarddhana telah terjadi pertentangan keluarga, antara Wikramawarddhana yang memerintah wilayah bagian barat (Majapahit) dengan Bhre Wirabhumi yang memerintah bagian timur (daerah Balambangan). Menurut Pararaton, peristiwa besar yang terjadi pada masa pemerintahan Wikramawarddhana, yang nyaris meruntuhkan Majapahit itu dikenal sebagai peristiwa Paregreg. Perang paregreg itu terjadi antara tahun $1323-1328 \mathrm{C}(1401$ - $1406 \mathrm{M})$. Dalam peristiwa itu Wikramawarddhana hampir kalah, tetapi setelah mendapat bantuan dari Bhre Tumapel (Bhra Hyang Parameswara), Bhre Wirabhumi dapat dikalahkan (Djafar, 1978: 45-46).

Sebuah situs yang ditemukan di daerah Blitar di dekat Candi Sawentar yang kemudian disebut Candi Sawentar II kemungkinan merupakan sebuah monumen peringatan yang menggambarkan peristiwa perang paregreg tersebut. Candi ini didirikan tahun $1358 \mathrm{C}(1436 \mathrm{M})$ sesuai dengan angka tahun yang tertera di ambang pintu miniatur candi. Pada miniatur candi tersebut juga terdapat panil-panil berupa relief binatang. Dua di antara panil-panil relief binatang tersebut kemungkinan merupakan angka tahun berupa gambar (sengkalan memet). Angka-angka tahun yang disebutkan dalam pararaton tentang peristiwa Paregreg ternyata sangat dekat bahkan ada yang sama dengan candra sengkala atau sengkalan memet yang dipahatkan pada relief-relief di Candi Sawentar II. Gambar seekor naga bermahkota sedang menggigit matahari dapat dibaca "Nagaraja anahut surya" yang berarti tahun 1318 C (1396 M) sangat dekat dengan awal terjadinya peristiwa Paregreg, yang menurut Pararaton mulai tahun 1323 C $(1401 \mathrm{M})$. Sedangkan gambar Ganeça menggigit matahari yang berdiri diantara dua ekor harimau dapat dibaca "Ganeça inapit mong anahut Surya" berarti tahun 1328 C (1406 M) sama dengan tahun berakhirnya Paregreg, yaitu saat terbunuhnya Bhre Wirabhumi (Tjahjono, 2000: 42-43). Menurut Pararaton peristiwa itu dinyatakan dengan candra sengkala yang berbunyi "Nagalara anahut wulan" yang berarti tahun 1328 C (1406 M) (Djafar, 1978).

Apabila diamati dari makna penggambaran naga yang mengenakan mahkota, sangat mungkin hal itu merupakan simbolisasi seorang raja yang marah, dan digambarkan sedang berusaha menelan matahari. Sedangkan matahari yang dicaplok nagaraja tersebut merupakan simbolisasi dari kekuasaan kerajaan Majapahit yang sedang dicabik-cabik untuk diruntuhkan. Sebab matahari yang digambarkan pada panil itu adalah "Surya Majapahit" yang merupakan lambang kebesaran Kerajaan Majapahit. Dengan demikian relief "Nagaraja anahut Surya" menggambarkan adanya upayaupaya untuk meruntuhkan kekuasaan Majapahit melalui perebutan tahta oleh Wirabhumi terhadap kekuasaan Wikramawarddhana (Tjahjono, 2000: 43-44). 
Pada tahun 1351 Ç (1429 M) Wikramawarddhana digantikan oleh putrinya yang bernama Suhita. Pada masa pemerintahannya inilah Candi Sawentar II itu didirikan, karena ia memerintah hingga tahun 1369 C (1447 M). Menurut Pararaton Suhita adalah anak kedua dari Bhra Hyang Wisesa (Wikramawarddhana). Kemungkinan ibu Suhita adalah putri Bhre Wirabhumi. Sehingga kemungkinan ia dijadikan raja dengan maksud untuk meredakan persengketaan antara pihak keluarga Wikramawarddhana dengan keluarga Wirabhumi (Krom, 1931: 446; Soekmono, 1961: 71; Djafar, 1978: 46-47).

Pertentangan keluarga itu ternyata terus berlangsung, yang ditandai dengan dibunuhnya Raden Gajah karena dituduh telah memenggal kepala Bhre Wirabhumi. Sepeninggal Suhita pertentangan keluarga itu tak pernah reda, bahkan ketika Majapahit diperintah oleh Rajasawarddhana, ia memindahkan pusat pemerintahannya ke Keling-Kahuripan. Hal ini kemungkinan karena keadaan politik di Majapahit semakin memburuk. Rajasawarddhana meninggal tahun 1375 Ç (1453 M) (Djafar, 1978: 47).

Kemudian ketika Majapahit diperintah oleh Bhre Pandan Salas (Dyah Suraprabhawa Sri Singhawikramawarddhana), ia diserang oleh Bhre Kertabhumi pamannya sendiri. Bhre Pandan Salas menyingkir ke Daha dan meneruskan pemerintahannya sampai meninggal tahun 1396 C (1474 M). Ia digantikan oleh anaknya Dyah Ranawijaya yang bergelar Girindrawarddhana. Girindrawarddhana berusaha untuk mempersatukan kembali wilayah kekuasaan Majapahit yang telah terpecah-pecah akibat pertentangan keluarga. Pada tahun $1400 \mathrm{C}$ ia menyerang Majapahit, untuk merebut kembali kekuasaan Majapahit dari tangan Kertabhumi. Dalam penyerangan itu Bhre Kertabhumi gugur. Berita yang tersimpan dalam serat Kanda tentang keruntuhan Majapahit tahun 1400 C yang dinyatakan dengan candra sengkala sirna ilang kertaning bhumi, menurut Hasan Djafar haruslah ditafsirkan sebagai peristiwa gugurnya Bhre Kertabhumi di kedaton Majapahit (Djafar, 1978: 48-50).

Walaupun Girindrawarddhana telah berhasil mempersatukan kembali wilayah Majapahit yang terpecah-pecah itu, namun kekuasaan Majapahit tak dapat dipertahankan. Hal ini disebabkan selain karena keadaan Majapahit yang telah rapuh dari dalam juga karena timbulnya perkembangan-perkembangan baru di daerah pesisir utara Jawa dan di Asia Tenggara umumnya. Pertentangan-pertentangan dan perpecahan antara keluarga raja-raja dalam memperebutkan kekuasaan atas tahta kerajaan menyebabkan keadaan intern kerajaan Majapahit menjadi sangat lemah. Karena kelemahan tersebut, maka ketika tahun 1441 Ç (1519 M) mendapat serangan dari kerajaan Islam Demak runtuhlah kerajaan Majapahit dan hilang lenyaplah kekuasaan raja-raja Dinasti Girindra (Dinasti Rajasa) yang telah berkuasa selama hampir 300 tahun di kerajaan Singhasari dan Majapahit (Djafar, 1978: 108). 


\section{KEPUSTAKAAN}

Darmosoetopo, Riboet, 1993. Sejarah Perkembangan Majapahit, 700 Tahun Majapahit (1293-1993), Suatu Bunga Rampai, Surabaya: Dinas Pariwisata Daerah Provinsi Daerah Tingkat I Jawa Timur,.

Djafar, Hasan, 1978. Girindrawarddhana Beberapa Masalah Majapahit Akhir, Jakarta: Yayasan Dana Pendidikan Buddhis Nalanda,.

Poesponegoro, Marwati Djoened, dan Nugroho Notosusanto, 1984. Sejarah Nasional Indonesia II, Jakarta: P.N. Balai Pustaka.

Kartodirdjo, Sartono, 1993. Masyarakat dan Sistem Politik Majapahit, 700 Tahun Majapahit (1293-1993), Suatu Bunga Rampai, Surabaya: Dinas Pariwisata Daerah Provinsi Daerah Tingkat I Jawa Timur.

Krom, N.J., 1931.Hindoe-Javansche Geschiedenis, Tweede herziene druk, 'sGravenhage: Martinus Nijhoff.

Soekmono, 1961. Pengantar Sedjarah Kebudajaan Indonesia, 11, Djakarta: Trikarja.

Tjahjono, Baskoro Daru, 2000. Berita Penelitian Arkeologi, nomor 11, Candi Sawentar II di Blitar, Latar Belakang Sejarah dan Lingkungannya, Yogyakarta: Balai Arkeologi Yogyakarta.. 